\title{
First Record of an Isolate (Pathotype) of Puccinia striiformis f. sp. hordei the Causative of Stripe Rust on Barley in Egypt
}

\section{Mohdly, B.R. ${ }^{1}$; Khalil, A.E. ${ }^{1}$ and Amer, K.A. ${ }^{2}$}

1- Plant Pathology Research Institute, Agricultural Research Center, Giza, Egypt.

2- Field Crops Research Institute, Agricultural Research Center, Giza, Egypt.

uring 2018/2019 growing season, symptoms of stripe rust (yellow rust), caused by Puccinia striiformis f. sp. hordei, on barley leaves (Hordeum vulgare L.) were observed, specifically on (LIGNEE527/GERBEL/3/BOY/B*2/SURB//CI1225.2D/4/M104) and (Kv//Alger/Ceres.362/1/1/3/Arr/Esp//Alger/Ceres.362/1/1/4/CamB1// CI08887/CI05761/3/Kataja//Esp/1808/4L/5/Harmal02ArabiAbiad*2/4 /Soufara02/3/R1M508/Por//WI2269Nawair1) lines, grown in ElAlameen region - Marsa Matrouh governorate (Fig., 1). Isolation of the causative was carried out from single pustules, multiplied and the obtained urediospores were used to carry out pathogenicity test on the same lines. Typical symptoms caused by Puccinia striiformis f. sp. hordei were obtained after 14 days and found to be similar to those previously collected from infected barley samples. Definition of pathogen Pathotype of $P$. striiformis f. sp. hordei using the molecular biology method (RAPD) DNA showed 99\% similarity with Pathotype of Puccinia striiformis f. sp. hordei. On the basis of the Blast Fungi, Puccinia striiformis f. sp. hordei appeared high similarity with Pathotype as shown in (Fig., 2). This Isolate was recorded in the NCBI/gene bank under the number MN598662. This is the first record of the pathogen Pathotype of yellow rust in Egypt.

Keywords: barley, Hordeum vulgare, stripe rust, yellow rust, Puccinia striiformis f. sp. hordei. 
Fig. 1.

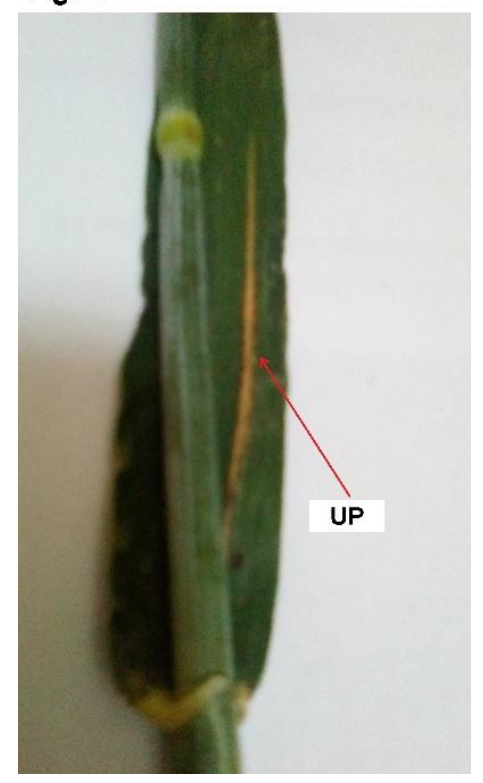

Fig. 2a.

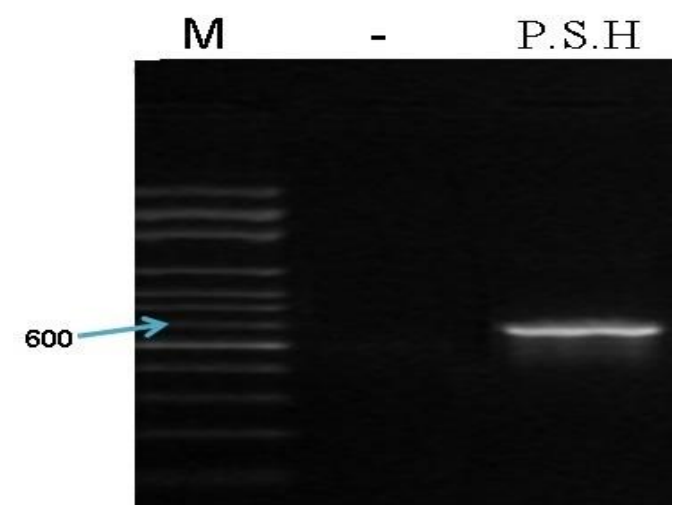

Fig. 2b.

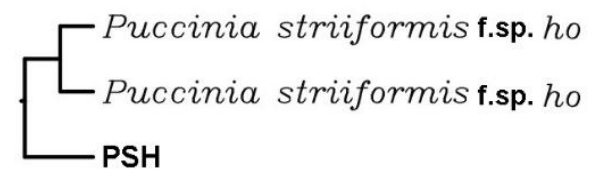

Fig.1. Typical barley stripe rust pustules on barley leaf uredial pustules (UP), naturally infected.

Fig. 2a. PCR products from amplification of ITS primer (ITS1F-ITS4R) region of rDNA of isolates. M: 100bp plus DNA Marker, -: negative sample, Puccinia striiformis f. sp. hordei (P.S.H) of Fung.

Fig. 2b. The Blast Identification Basis on the P.S.H. sequencing confirmed the fungal pathogen as Puccinia striiformis f. sp. hordei (pathotype). 


\section{التسجيل الأول لطرز ممرض (Pathotype) للفطر Puccinia striiformis f. sp. hordei الأصفر على الثعير فى مصر بدوى رجب حسن مهلى' ، أشرف السعيد خليل' ،و خيرى عبد

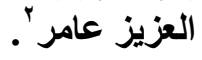

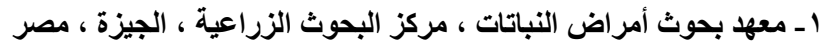

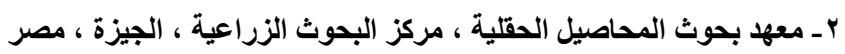

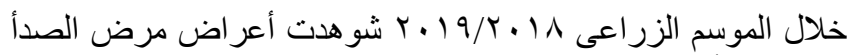

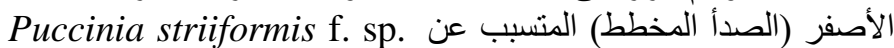

hordei,

(LIGNEE527/ GERBEL/3/BOY/B*2/ SURB// على السلالتين التى

CI1225.2D/4/M104) and

(Kv//Alger/Ceres.362/1/1/3/Arr/Esp//Alger/Ceres.362/

1/1/4/CamB1//CI08887/CI05761/3/Kataja//Esp/1808/4L/

5/Harmal02ArabiAbiad*2/4/Soufara02/3/R1M508/Por//

WI2269Nawair1)

المنزر عتين فى منطقة العلمين - محافظة مرسى مطروح (شكل (1). تم

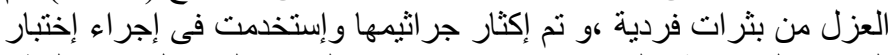

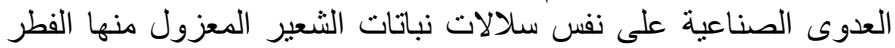

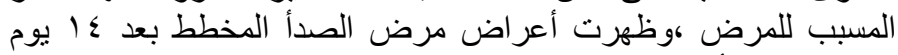

مطابقة لتلك لألأعر اض التى تم رصدها في عينات الثعير التى سبق جمعها.

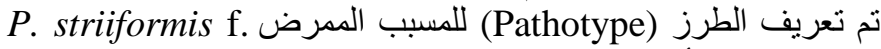

(RAPD) DNA. بأستخدام طريقة البيولوجية الجزيئة sp. hordei

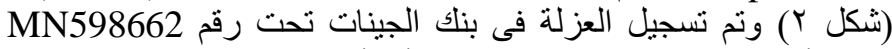

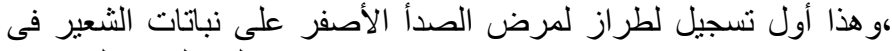

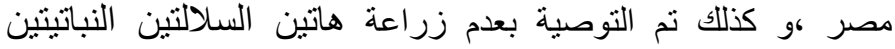
ل ل لساسيتهما وقابليتهما للاصابه. 